\title{
Length-weight relationships of four finfish commercial species from the southern Gulf of Mexico
}

\author{
Iván Velázquez-Abunader $^{1} \mathbb{D}$, Thierry Brulé ${ }^{1} \mathbb{D}$, Miguel A. Cabrera $^{1} \mathbb{D}$ \& Jorge A. López-Rocha $^{2}$ \\ ${ }^{1}$ Departamento de Recursos del Mar, Centro de Investigación y de Estudios Avanzados \\ Instituto Politécnico Nacional, Mérida, Yucatán, México \\ ${ }^{2}$ Laboratorio de Análisis Espacial de Zonas Costeras, Unidad Multidisciplinaria de Docencia e Investigación \\ Facultad de Ciencias, Universidad Nacional Autónoma de México \\ Sisal, Yucatán, México \\ Corresponding author: Jorge A. López-Rocha (jorgelopezrocha@ ciencias.unam.mx)
}

\begin{abstract}
The relationship between total length and total weight (LWR) of four commercial species of finfish captured in the southern Gulf of Mexico (Lachnolaimus maximus, Ocyurus chrysurus, Mycteroperca bonaci, and Mycteroperca microlepis) was estimated. Two of these species are captured in the region by the small-scale fleet, while the other two are targeted by small-scale and semi-industrial fleets using harpoons, handlines, and long-lines. For the assessment, the organisms were sampled at the landing decks in the study area in two periods: 1996-1999 (semi-industrial fleet) and from April 2017 to May 2018 (small-scale fleet). A total of 2780 individuals were sampled which 2775 individuals were used to obtain LWR functions. The four species showed negative allometric growth with $b<3$ for the 2017-2018 period, two species showed positive allometric growth with $b>3$ for the 1996-1999 period. This type of information is an important input for the stock assessment of these species that support important fisheries in the zone and are under high fishing pressure levels.
\end{abstract}

Keywords: Lachnolaimus maximus; Ocyurus chrysurus; Mycteroperca bonaci; Mycteroperca microlepis; allometry; Campeche Bank

The function that defines the length-weight relationship (LWR) of species targeted by worldwide different fishing fleets provides necessary inputs for stock assessment of those species. This function is commonly used as inputs in the fisheries models that support management advice for decision-makers (Froese 2006, Alavi-Yeganeh et al. 2016).

In the southern Gulf of Mexico (Yucatan continen-tal shelf), fishes of the families Epinephelidae, Lutjanidae, and Labridae, comprise an important component of the multi-species fishery associated with the red grouperblack grouper fishery. An annual average catch of 7800 t has been recorded between 2005 and 2014 (DOF 2018); in the 1970s, it reached up to 20,000 t (DOF 2012). Concerns about highly fluctuating catches led to calls for the updated assessment of all targeted species in this fishery. These species are captured up to $\sim 23^{\circ} \mathrm{N}$ ( $50 \mathrm{~m}$ depth) mainly with three fishing gears: harpoons, handlines, and long-lines (Quijano et al. 2018). The fishery has a high relevance due to the economic income generated by this activity (Saldaña et al. 2017); however, despite its importance, the biological knowledge of most of the species harvested in this region is scarce, and therefore the current status of several stocks included in the catches is generally unknown (Salas et al. 2006). Some studies have suggested that in this region, the capture of these species (especially those of the Epinephelidae family) is sequentially where the juvenile organisms are concen-trated mainly in areas near the coast while the adults are captured in deeper waters (López-Rocha \& Arreguín-Sánchez 2008).

Within this context, the present contribution provides estimates of the LWR function (and its parameters) of four finfish species of commercial importance captured in the southern Gulf of Mexico

Corresponding editor: Patricio M. Arana 


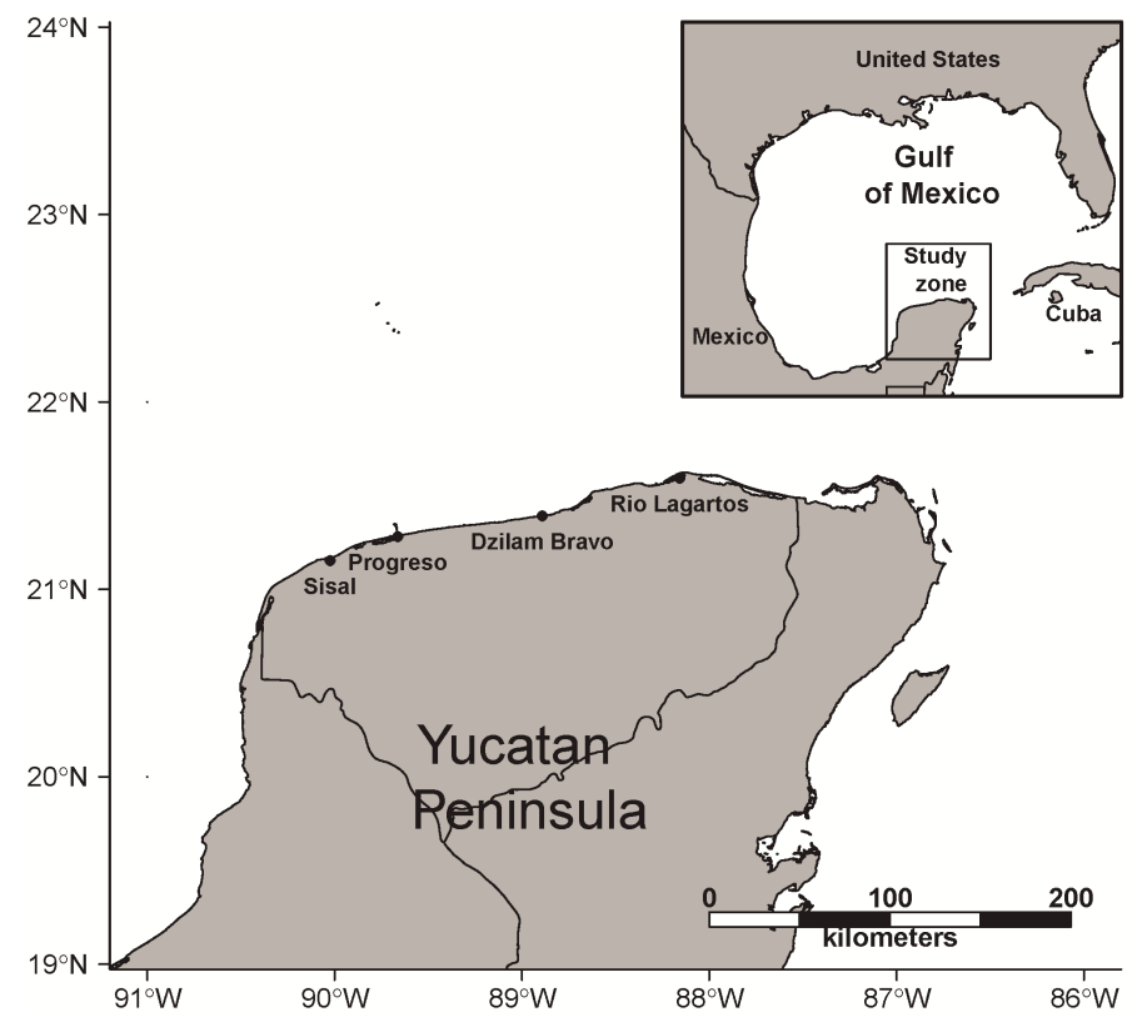

Figure 1. Location of landing ports. The small-scale fleet operates from the coast to a depth of approximately $20 \mathrm{~m}\left(\sim 22^{\circ} \mathrm{N}\right)$, and the industrial fleet operates from 20 to $\sim 50 \mathrm{~m}$ depth $\left(\sim 23^{\circ} \mathrm{N}\right)$, landing in Progreso Port (Quijano et al. 2018).

during both periods: the hogfish Lachnolaimus maximus (Walbaum, 1792), the yellowtail snapper Ocyurus chrysurus (Bloch, 1791), the black grouper Mycteroperca bonaci (Poey, 1860), and the gag grouper Mycteroperca microlepis (Goode \& Bean, 1879).

In the period from April 2017 to May 2018, $L$. maximus, O. chrysurus, M. bonaci, and M. microlepis were sampled and measured monthly at the small-scale fleet landing ports: Sisal $\left(21^{\circ} 09^{\prime} 55^{\prime \prime} \mathrm{N}, 90^{\circ} 01^{\prime} 50^{\prime \prime} \mathrm{W}\right)$,

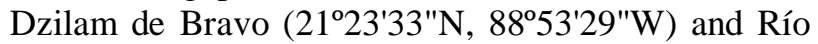
Lagartos $\left(21^{\circ} 35^{\prime} 51^{\prime \prime N}, 8^{\circ} 09^{\prime} 28^{\prime \prime} \mathrm{W}\right)$ (Fig. 1). Additional information was included for $M$. bonaci and $M$. microlepis from the semi-industrial fleet in 1996-1999. The semi-industrial fleet generally operates along with the Campeche Bank at depths up to $\sim 50 \mathrm{~m}$ (up to $\sim 23^{\circ} \mathrm{N}$ ), landing in Progreso port (Fig. 1) (Quijano et al. 2018), because M. bonaci and M. microlepis show depth-related segregation by size in the southern Gulf of Mexico. Juveniles are found in shallow waters, while adults are in deeper waters, where the small-scale fleet operates, and the semi-industrial fleet operates, respectively (Brulé et al. 2003a).

Individual fishes were measured in terms of total length $(\mathrm{TL} \pm 0.1 \mathrm{~cm})$ and the gutted weight $(\mathrm{GW} \pm 0.1$ g) of the organisms (all fishes were landed eviscerated). The GW data was converted to total weight (TW) and calculated from data previously obtained by Brulé et al. (2003a,b), Trejo-Martinez et al. (2011), and NohQuiñones (unpubl. data), using a function that defines the GW-TW relationship. All these relationships with $R^{2}>0.90$. Therefore, it was assumed that the estimation bias was low. The above in order that our results are comparable with those of other studies.

Using log (TL) - log (TW) plots, an exploratory analysis facilitated the detection of outliers; extreme outliers were attributed to error measurements and were eliminated from the analysis (Froese 2006, AlaviYeganeh et al. 2016, Zulkafli et al. 2016).

The LWRs were estimated through the equation TW $=a \mathrm{TL}^{b}$, where $a$ is the intercept and $b$ is the slope, also known as the allometric coefficient (Ricker 1975, Domingues et al. 2016). It was necessary to transform the previous equation into its linear form: $\log (\mathrm{TW})=$ $\log a+b \log$ (TL) (Ricker 1975) to estimate the values of parameters $a$ and $b$. The confidence intervals (CI) of $a$ and $b(95 \%)$ were estimated, and the goodness of fit in each case was evaluated by the criterion of $R^{2}$ (Sokal $\&$ Rohlf 1995). The estimated values of $b$ were analyzed using a Student's $t$-test in order to determine 


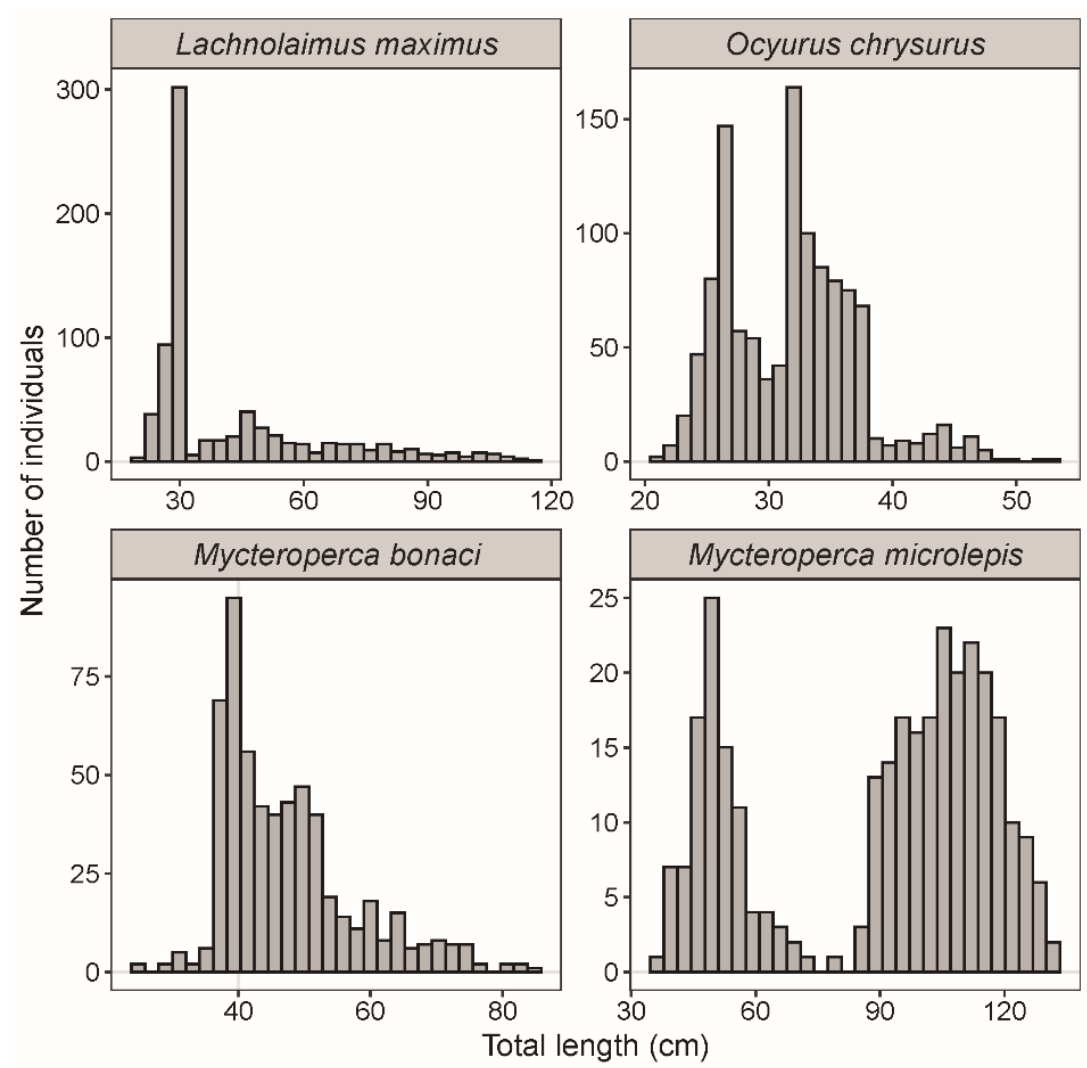

Figure 2. Total length-frequency distributions of the four studied species captured by small-scale fleet and industrial fleets in the southern Gulf of Mexico.

whether growth is isometric (Ho: $b=3$ ) or allometric (Ha: $b \neq 3$ ) (Zar 1999, Velázquez-Abunader et al. 2016), using the following equation:

$$
\hat{t}=\frac{S D_{T L}}{S D_{T W}} \times \frac{|b-3|}{\sqrt{1-R^{2}}} \times \sqrt{n-2}
$$

where $\hat{t}$ is the Student's $t$ value, $\mathrm{SD}_{\mathrm{TL}}$ is the standard deviation of length, $\mathrm{SD}_{\mathrm{Tw}}$ is the standard deviation of total weight, $R^{2}$ is the determination coefficient, and $n$ is the number of observations (Pauly 1984). The analyses were carried out with the basic package of the programming language $R$ (R Core Team 2020).

In both periods, 2780 individuals of the four species were collected (except for $L$. maximus and $O$. chrysurus, no information was available in 1996-1999). Five outliers were omitted from the analysis, leaving 2775 data to obtain the LWR functions. The minimum TL recorded was $20 \mathrm{~cm}$ for $L$. maximus, while the longest animal corresponded to M. microlepis with a length of $132 \mathrm{~cm}$ TL (Fig. 2). The goodness of fit of all models for the respective LWR functions was highly significant $(P<0.001)$. For the four finfish species, the value of $b$ was statistically lower than three $(P<0.05)$ in the 2017-2018 period, indicating a negative allome- tric growth, while for the period 1996-1999, the two sampled species showed positive allometric growth (b $>3 ; P<0.05$ ) (Table 1).

Despite these species' commercial importance, LWR estimates for these species in the Gulf of Mexico are scarce (for example, in FishBase database; Froese $\&$ Pauly 2018). The total of LWR functions reported in this study, the coefficient of determination $\left(R^{2}\right)$ was greater than 0.91 , which indicates a low dispersion of the data and that the models can be good predictors of TW. The values of the slope $b$ were within range the common range reported for fishes' species $(2.500<b<$ 3.500 ) suggested by Froese (2006), except $L$. maximus, which a $b$ value less than $2.5(b=2.4340)$ (Table 1$)$.

Lachnolaimus maximus had negative allometric growth $(b<3)$, like that reported for this species in other regions of the Gulf of Mexico and the Caribbean Sea (Froese \& Pauly 2018). For L. maximus, estimation of population parameters by region is particularly important because the reproductive exchange of this species is geographically limited (Collins \& McBride 2015, Seyoum et al. 2015).

The negative allometric growth estimated in this study for $O$. chrysurus $(b=2.7823)$ is consistent with a 


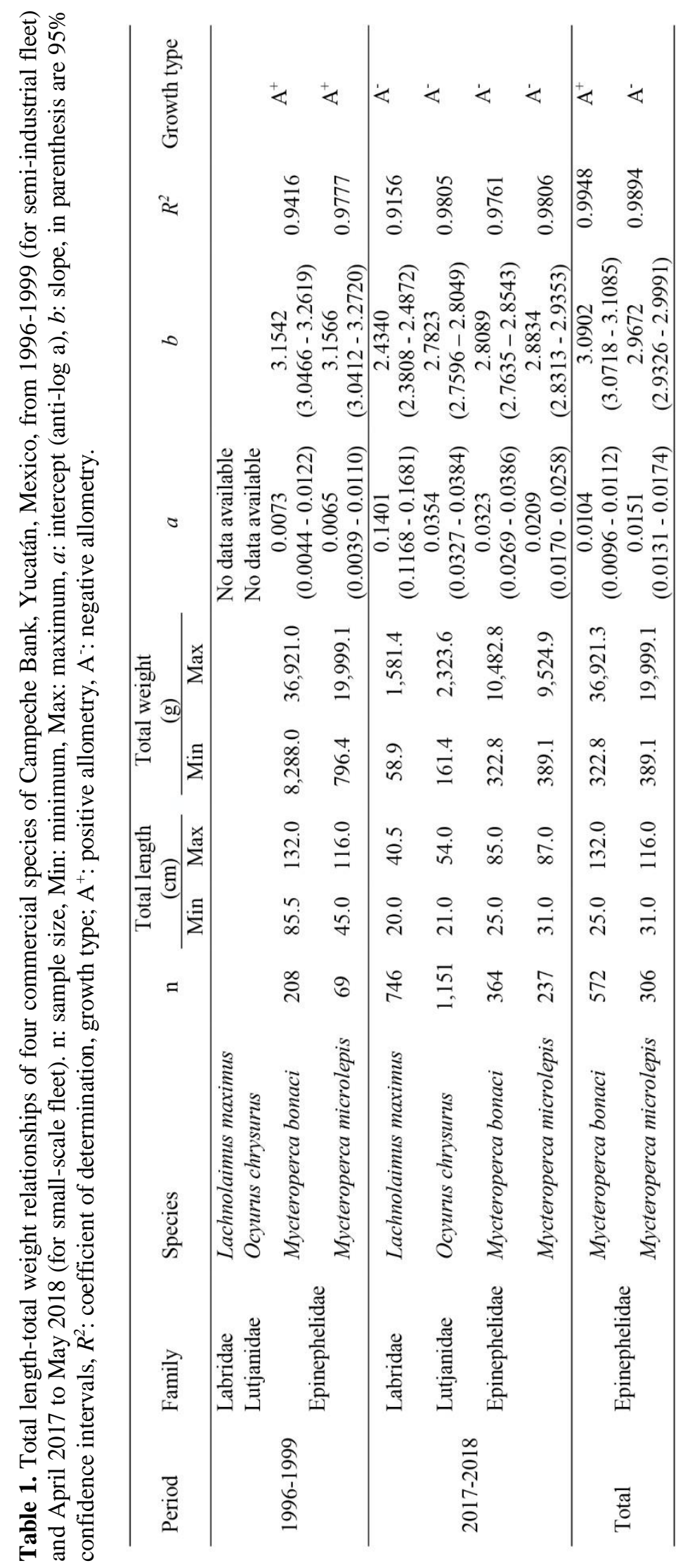


value estimated in the Caribbean Sea and Brazil $(b=$ $2.747 \pm 0.141$ ) (Froese \& Pauly 2018) and also from those reported in Florida, USA by García et al. (2003) $(b=2.760-2.830)$ and Allman et al. (2005) $(b=2.930)$.

M. bonaci and $M$. microlepis showed positive allometric growth $(b>3)$ in the 1996-1999 period, while in the 2017-2018 period, their growth was negative allometric $(b<3)$. These differences in the type of growth in these species have been found in other regions of the world. It has been recorded that $M$. bonaci shows negative allometric growth in the northeastern region of Brazil $(b=2.55)$ (Froese \& Pauly 2018 ), in contrast with other regions of the world, where positive allometric growth $(b>3)$ has been reported, especially in the USA (Manooch III \& Mason 1987, Crabtree \& Bullock 1998). In the case of $M$. microlepis, negative allometric growth was found $(b<$ 3) like that reported in the south-eastern USA (Manooch III \& Haimovici 1978). The differences found in the type of growth for these two species could be due to differences in age or sizes in the organisms sampled in both periods since organisms of greater size tend to increase in weight, height, or width in a greater proportion than in size (Froese 2006), which suggests that in these species there are differences in growth likely due to their ontogenetic development (stanzas growth).

It was observed that the maximum TL of the species registered here is below those reported in other regions (consulted on Fishbase database: http://www. FishBase.org) because the specimens of L. maximus and $O$. chrysurus collected for this study come from small-scale fleet catches that operate due to the large extension of the continental shelf known as Campeche Bank, in a depth range of up to $20 \mathrm{~m}$. In this sense, it has been reported that $L$. maximus moves offshore with growth (Collins \& McBride 2011). O. chrysurus has a pattern of movements and heterogeneous distribution of juveniles associated with shallow areas and with seagrass and mangrove zones (Nagelkerken et al. 2000). Authors such as Trejo-Martínez et al. (2011) for $O$. chrysurus and Noh-Quiñones (unpubl. data) for $L$. maximus captured both adults and juveniles in areas of operation of the Campeche Bank of the small-scale fleet.

The results reported by this study contribute to the biological knowledge of the species, which is of importance for $L$. maximus, $M$. microlepis and $M$. bonaci, which are considered by the IUCN within the Red List of Threatened Species, as vulnerable and near threatened (Choat et al. 2010, Koenig et al. 2018, Padovani-Ferreira et al. 2018). The LWR functions' values had not been previously recorded in FishBase for the southern Gulf of Mexico region; hence they denote an important input for the stock assessment of these species, currently exposed to high fishing pressure.

\section{ACKNOWLEDGMENTS}

To the project CONACyT CB 252215 "Caracterización de la pesca artesanal en la península de Yucatán: identificando unidades de manejo", for the financial support to undertake this research. Thanks for the technical assistance provided by T. Colás-Marrufo and $X$. Renán-Galindo for data collection and analysis of $M$. bonaci and M. microlepis in the estimation of TW-GW relationships and analysis of data in the period 19961999. The authors thank Silvia Salas for her revisions and contributions to the document.

\section{REFERENCES}

Alavi-Yeganeh, M.S., Shojaei, M., Motlagh, S.A.T., Hakimelahi, M. \& Mirghaed, A.T. 2016. Lengthweight relationships of five commercial fish species from the Strait of Hormuz in the Persian Gulf. Journal of Applied Ichthyology, 32: 1266-1267. doi: 10.1111/ jai.13109

Allman, J.A., Barbieri, L.R. \& Bartels, C.T. 2005. Regional and fishery-specific patterns of age and growth of yellowtail snapper, Ocyurus chrysurus. Gulf of Mexico Science, 23: 211-223. doi: 10.18785/goms. 2302.08

Brulé, T., Deniel, C., Colás-Marrufo, T. \& Renan, X. 2003a. Reproductive biology of gag in the southern Gulf of Mexico. Journal of Fish Biology, 63: 15051520. doi: 10.1111/j.1095-8649.2003.00263.x

Brulé, T., Renán, X., Colás-Marrufo, T., Hauyon, Y., TuzSulub, A. \& Déniel, C. 2003b. Reproduction in the protogynous black grouper Mexico (Mycteroperca bonaci (Poey)) from the southern Gulf of Mexico. Fishery Bulletin, 101: 463-475.

Choat, J.H., Pollard, D. \& Sadovy, Y.J. 2010. Lachnolaimus maximus (errata version published in 2018). The IUCN Red List of Threatened Species 2010: e.T11130A124708500. https://dx.doi.org/ 10.2305/IUCN.UK.2010-4.RLTS.T11130A3252395. en. Downloaded on 23 March 2021.

Collins, A.B. \& McBride, R.S. 2011. Demographics by depth: spatially explicit life-history dynamics of a protogynous reef fish. Fishery Bulletin, 109: 232-242.

Collins, A. \& McBride, R. 2015. Variations in reproductive potential between nearshore and offshore spawning contingents of hogfish in the eastern Gulf of Mexico. Fisheries Management and Ecology, 22: 113124. doi: 10.1111/fme. 12102 
Crabtree, R.E. \& Bullock, L.H. 1998. Age, growth, and reproduction of black grouper, Mycteroperca bonaci. Fishery Bulletin, 96: 735-753.

Diario Oficial de la Federación (DOF). 2018. Acuerdo por el que se da a conocer la actualización de la carta nacional pesquera. Gobierno de México, Ciudad de México. [http://dof.gob.mx/nota_detalle.php?codigo= 5525712]. Reviewed: June 11, 2019.

Diario Oficial de la Federación (DOF). 2012. Acuerdo por el que se da a conocer la actualización de la carta nacional pesquera. Gobierno de México, Ciudad de México. [http://dof.gob.mx/nota_detalle.php?codigo= 5265388]. Reviewed: August 24, 2019.

Domingues, R.R., Caltabellotta, F.P. \& Amorim, A.F. 2016. Length-length and length-weight relationships of Carcharhinus falciformis and C. signatus (Carcharhinidae: Carcharhinus) caught by commercial fisheries in the Southwest Atlantic Ocean. Regional Studies in Marine Science, 6: 83-86. doi:dx.doi.org/10.1016/ j.rsma.2016.03.014

Froese, R. 2006. Cube law, condition factor, and weightlength relationships: history, meta-analysis, and recommendations. Journal of Applied Ichthyology, 22: 241-253. doi: 10.1111/j.1439-0426.2006.00805.x

Froese, R. \& Pauly, D. 2018. FishBase. World Wide Web electronic publication. [http://www. FishBase. org]. Reviewed: March 4, 2019.

Garcia, E.R., Potts, J.C., Rulifson, R.A. \& Manooch, C.S. 2003. Age and growth of yellowtail snapper, Ocyurus chrysurus, from the southeastern United States. Bulletin of Marine Science, 72: 909-921.

Koenig, C., Bertoncini, A.A. \& Ferreira, B. 2018. Mycteroperca microlepis. The IUCN Red List of Threatened Species 2018: e.T14050A46910927.https: //dx.doi.org/10.2305/IUCN.UK.2018-2.RLTS.T1405 0A46910927.en. Downloaded on 23 March 2021.

López-Rocha, J.A. \& Arreguín-Sánchez, F. 2008. Spatial distribution of red grouper Epinephelus morio (Serranidae) catchability on the Campeche Bank of Mexico. Journal of Applied Ichthyology, 24: 282-289. doi: 10.1111/j.1439-0426.2008.01070.x

Manooch III, C.S. \& Haimovici, M. 1978. Age and growth of the gag, Mycteroperca microlepis, and size-age composition of the recreational catch off the southeastern United States. Transactions of the American Fisheries Society, 107: 234-240. doi: 10.1577/15488659(1978)107<234:AAGOTG>2.0.CO;2

Manooch III, C.S. \& Mason, D.L. 1987. Age and growth of the Warsaw grouper and black grouper from the southeast region of the United States. Northeast Gulf Science, 9: 65-75. doi: 10.18785/negs.0902.01
Nagelkerken, I., Van der Velde, G., Gorissen, M., Meijer, G., Van't Hof, T. \& Den Hartog, C. 2000. Importance of mangroves, seagrass beds, and the shallow coral reef as a nursery for important coral reef fishes using a visual census technique. Estuarine, Coastal and Shelf Science, 51: 31-44. doi: 10.1006/ecss.2000.0617

Padovani-Ferreira, B., Bertoncini, A.A., Pollard, D.A., Erisman, B., Sosa-Cordero, E., Rocha, L.A., AguilarPerera, A. \& Brule, T. 2018. Mycteroperca bonaci. The IUCN Red List of Threatened Species 2018: e.T132724A46916253.https://dx.doi.org/10.2305/IU CN.UK.2018-2.RLTS.T132724A46916253.en.Downloaded on 23 March 2021.

Pauly, D. 1984. Fish population dynamics in tropical waters: a manual for use with programmable calculators. ICLARM Studies and Review, 8. ICLARM, Penang.

Quijano, D., Salas, S., Monroy-García, C. \& VelázquezAbunader, I. 2018. Factors contributing to technical efficiency in a mixed fishery: Implications in buyback programs. Marine Policy, 94: 61-70. doi: 10.1016/ j.marpol.2018.05.004

R Core Team. 2020. R: a language and environment for statistical computing. Vienna, Austria. [https://www. R-project.org/]. Reviewed: January 4, 2020.

Ricker, W.E. 1975. Computation and interpretation of biological statistics of fish populations. Bulletin Fisheries Research Board of Canada, 191: 1-382.

Salas, S., Mexicano-Cíntora, G. \& Cabrera, M.A. 2006. ¿Hacia dónde van las pesquerías en Yucatán?: tendencias, retos y perspectivas. Cinvestav Press, Mérida.

Saldaña, A., Salas, S., Arce-Ibarra, A.M. \& Torres-Irineo, E. 2017. Fishing operations and adaptive strategies of small-scale fishers: insights for fisheries management in data-poor situations. Fisheries Management and Ecology, 24: 19-32. doi: 10.1111/fme.12199

Seyoum, S., Collins, A.B., Puchulutegui, C., McBride, R.S. \& Tringali, M.D. 2015. Genetically determined population structure of hogfish (Labridae: Lachnolaimus maximus) in the southeastern United States. Fishery Bulletin, 113: 442-455. doi: 10.7755/FB.113.4.7

Sokal, R.R. \& Rohlf, F.J. 1995. Biometry, the principles, and practices of statistics in biological research. W.H. Freeman Press, New York.

Trejo-Martínez, J., Brulé, T., Mena-Loría, A., ColásMarrufo, T. \& Sánchez-Crespo, M. 2011. Reproductive aspects of the yellowtail snapper Ocyurus chrysurus from the southern Gulf of Mexico. Journal of Fish Biology, 79: 915-936. doi: 10.1111/j.10958649.2011.03062.x

Velázquez-Abunader, I., López-Rocha, J.A., ArellanoMartínez, M., Ceballos-Vázquez, B.P. \& Cabrera, M. 
2016. Estimation of growth parameters in a wild population of lion-paw scallop (Nodipecten subnodosus) in Bahia de Los Angeles, Baja California, Mexico. Hidrobiologica, 26: 133-142.

Zar, J.H. 1999. Biostatistical analysis. Prentice-Hall Press, New Jersey.

Received: January 24, 2020; Accepted: February 26, 2021
Zulkafli, A.R., Amal, M.N.A., Shohaimi, S., Mustafa, A., Ghani, A.H., Hashim, S., et al. 2016. Length-weight relationships of 15 fish species from Tembeling River, Pahang, Malaysia. Journal of Applied Ichthyology, 32: 167-168. doi: 10.1111/jai.12939 